\title{
人屍体に於ける肺水腫の病理組織学的考察
}

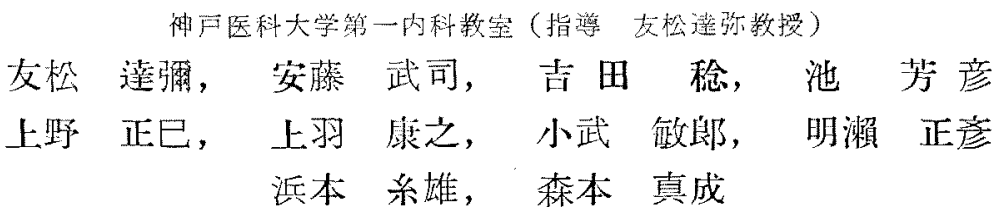

\section{PATHOHISTOLOGICAL CONSIDERATION ON THE PULMONARY EDEMA IN MEN \\ $\mathrm{BY}$}

T. Tomomatsu, T. Andō, M. Yoshida, Y. Ike, M. Ueno, Y. Ueba, T. Odake, M. Akase, I. Hamamoto and M. Morimoto,

The Ist Department of Internal Medicine, Kobe Medical College (Prof.: Tatsuya Tomomatsu)

Pathohistological study on the pulmonary edema was performed in 248 cases. Pulmonary edema was divided into two forms, i.e. intraalveolar and interstitial.

Of 248 cases pulmonary edema in alveolar cavity was found in $106(42.7 \%)$, in connective tissue $64(25.8 \%)$, and combined 58 , only in alveolar cavity 23 , and in connective tissue 5 .

Some discussion has been made on the pathogenesis of interstitial edema, especially on the fact that both intraalveolar and interstitial edema were not found concurrently.

In contrast to the inflammatory type, derangement of nervous control is thought to contribute some part in producing the pulmonary edema in congestive type usually seen in the nervous, cardiovascular, and renal diseases.

\section{緒言}

肺水腫の発生に関し現在迄臨床的並ざに実駼的 研究により幾多の因子が挙代ら机ている汃，ての 発生機構に関しては未だ確か疗る説を見ない。 Altschule1）の列記せる如き多くの因子加幾つか

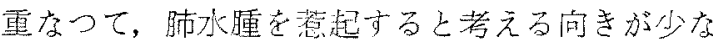
くない.Cameron 2)は热選択に集めた100例の剖 検所見から循環器系，中枢神経系及び多発性骨折 時然に於ける肺水腫の笔生頻度につき, 特に循環 器系の中, 高血圧, 慢性腎炎, 冠動脈閉塞, 僧帽
弁狄窄，訤障書に高率疗る事を報告している。 Luisada $^{3 ） は}$ は眠水腫発生を高頻度に来たす臨床疾

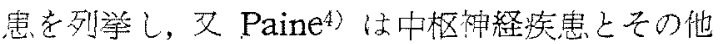
の疾患におけ当肺水腫の発生頻度更び肺水腫発生 例に的ける循環路障害の有無につき䖽討を加え， 中枢神経筷患にて高率に脑水腫の発生をみ，かつ その大部分が循環器障害紊生前有していた事を明

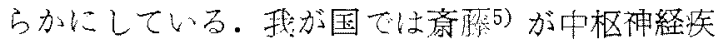
患上，心障害の合併の際肺水腫発生頻度が高い事

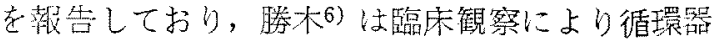


Table I. Correlation between Intraalveolar and Interstitial Edema

\begin{tabular}{|c|c|c|c|c|c|}
\hline & \multicolumn{3}{|c|}{ Interstitial Edema } & \multirow[t]{2}{*}{ Total } \\
\hline & & Marked & Minimal & Negative & \\
\hline \multirow{3}{*}{ 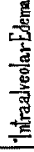 } & Marked & 58 & 25 & 23 & 106 \\
\hline & Minimal & 1 & 8 & 26 & 35 \\
\hline & Negative & 5 & 17 & 85 & 107 \\
\hline \multicolumn{2}{|c|}{ Total } & 64 & 50 & 134 & 248 \\
\hline
\end{tabular}

Table II. Incidence of Pulmonary Edema in Variety of Disease

\begin{tabular}{|c|c|c|c|c|c|}
\hline & \multirow{2}{*}{$\begin{array}{l}\text { No. of } \\
\text { Cases }\end{array}$} & \multicolumn{2}{|c|}{ Intresiloolar Edema } & \multicolumn{2}{|c|}{ Interstitial Edema } \\
\hline & & $\begin{array}{l}\text { No. of } \\
\text { Cases }\end{array}$ & $\%$ & $\begin{array}{l}\text { No of } \\
\text { Cases }\end{array}$ & $z$ \\
\hline Centralnervous & 60 & 41 & 68.3 & 24 & 40.0 \\
\hline Respirstory & 94 & 54 & 57.4 & 37 & 39.4 \\
\hline Cardiavascular & 21 & 9 & 429 & 4 & 19.0 \\
\hline Kidneys & 14 & $q$ & 64.3 & 8 & 57.1 \\
\hline Blood & 25 & 11 & 44.0 & 5 & 20.0 \\
\hline Digestive & 51 & 13 & 25.5 & 6 & 11.8 \\
\hline Miscellaneous & 52 & 23 & 44.3 & 13 & 25.0 \\
\hline
\end{tabular}

疾患，中枢神経疾㭧，その他の三つに大别し，そ の掞の抢のに於ける肺水腫の発生頻度につき調查

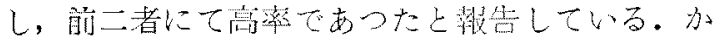
くの如く何れも循環器疾患态び中枢神経疾患にて

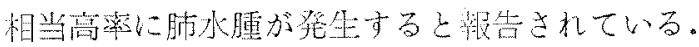
実験的肺水腫の研究にても，神経性因子が近来重 琵視されてきつ〉ある。我々も又如何なる疾患に 肺水腫が発生するか，その频度及げ病理学的所見 加ら，肺水腫の成因考考察し，その原因の解明に 資する目的で，本学にて剖桧せる218例の剖検肺 につきその病理組織像を観察した。

\section{材料}

昭和25年より32年に至る約 400 例の剖桧材料 中, 研究材料として有用なる 218 例の肺につき検 索した。肺はホルマリン固定をなし保存子るもの である。

方法：帕の各刑より切片在作成し， Mayer ○ Hematoxylin 染色, Van Gieson 染色更に一 部は鍍銀染色を施した。肺の病理組織像の模索に

Table III. Pathohistological Finding of the Intraalveolar Edema in Marked and Negative Group

\begin{tabular}{|c|c|c|c|c|c|c|c|c|c|c|c|c|c|c|c|c|c|}
\hline & \multicolumn{5}{|c|}{ Leucocyte Infiltration } & \multicolumn{5}{|c|}{ Congestion } & \multicolumn{5}{|c|}{ Bleeding } & \multirow[t]{2}{*}{ Total } \\
\hline 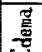 & & + & + & + & \pm & - & + & $\#$ & + & \pm & - & 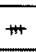 & $\pi$ & + & \pm & - & \\
\hline$\frac{1}{\frac{5}{5}}$ & Marked & 0 & 32 & 42 & 33 & 28 & 10 & 31 & 57 & 5 & 3 & 3 & 3 & 37 & 20 & 43 & 106 \\
\hline$\frac{\mathrm{g}}{\mathrm{c}}$ & Minima & 0 & 1 & 3 & 8 & 23 & 0 & 6 & 11 & 10 & 8 & 1 & 2 & 2 & 4 & 26 & 35 \\
\hline 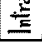 & Negative & 0 & 1 & 11 & 20 & 75 & I & 12 & 31 & 11 & 52 & 0 & 2 & 7 & 1 & 97 & 107 \\
\hline
\end{tabular}

Table IV. Pathohistological Finding in Edema and Non-edema Group in Variety of Disease

\begin{tabular}{|c|c|c|c|c|c|c|c|c|c|c|c|c|c|c|c|c|c|c|c|c|c|c|}
\hline & \multicolumn{7}{|c|}{ Intraalveolar Edema } & \multicolumn{7}{|c|}{ Intraalveolar Edema } & \multicolumn{7}{|c|}{ Intraalveolar Edema } & \\
\hline & \multicolumn{4}{|c|}{ Marked } & \multicolumn{3}{|c|}{ Interstitial Edema } & \multicolumn{4}{|c|}{ Minimal } & \multicolumn{3}{|c|}{ Interstitial Edema } & \multicolumn{4}{|c|}{ Negative } & \multicolumn{3}{|c|}{ Interstitial Edema } & \\
\hline & \begin{tabular}{|l} 
No. of \\
Cases \\
\end{tabular} & L. & C. & B. & + & \pm & - & \begin{tabular}{|l|l|}
$N_{0}$ of \\
Cases \\
\end{tabular} & L. & C. & B & + & \pm & - & \begin{tabular}{|l|} 
No. 1 \\
Cases
\end{tabular} & L. & C. & B. & + & \pm & - & \\
\hline Centralnervous & 41 & 11 & 37 & 17 & 22 & $T$ & 12 & 6 & 0 & 5 & 1 & 1 & 2 & 3 & 13 & 0 & 6 & 1 & 1 & 1 & 11 & 60 \\
\hline Respiratory & 54 & 38 & 52 & 39 & 33 & 13 & 8 & 13 & 1 & 1 & 1 & 1 & 2 & 10 & 27 & 2 & 6 & 1 & 3 & 5 & 19 & 94 \\
\hline Cardiovascilar & 9 & 2 & 9 & 4 & 4 & 4 & I & 1 & 0 & 1 & 0 & 0 & 0 & 1 & 11 & 2 & 10 & 3 & 0 & 5 & 6 & 21 \\
\hline Kidneys & 9 & 1 & 8 & 0 & 8 & $I$ & 0 & I & 0 & 0 & 1 & 0 & 1 & 0 & 4 & 0 & 1 & 0 & 0 & 0 & 4 & 14 \\
\hline Blood & 11 & 8 & 10 & 4 & 5 & 3 & 3 & 1 & 0 & 0 & 0 & 0 & 0 & 1 & 13 & $I$ & 7 & 1 & 0 & 2 & 11 & 25 \\
\hline Digestive & 13 & 7 & 11 & 7 & 5 & 5 & 3 & 7 & 1 & 3 & 2 & 0 & 3 & 4 & 31 & 4 & 13 & 1 & 1 & 4 & 26 & 51 \\
\hline Miscellaneous & 23 & 12 & 22 & 10 & 12 & 5 & 6 & 5 & 1 & 4 & 1 & 0 & 2 & 3 & 24 & 2 & 11 & 1 & 1 & 4 & 19 & 52 \\
\hline
\end{tabular}


当つては, 肺胞内の肺水腫, 白血球㳙出, 出血, 肺 毛細血管のうつ血，肺間質内の肺水腫の有無及び 程度につき顕微鏡学的钼察を行なつた．肺胞内肺 水腫については次の如くその程度を分類した。

a）强度。殆に゙全視野に゙亘り，瞄胞腔が水腫液 にて充満されているもの．b）中等度. 数視野 に亘り水腫液が肺胞空を満しておるもの．c) 弱陽性. 数コ乃至10数コの水腫液に満たされた肺 胞腔が集節性に，かつ鼻嶼狀に認められるもの.

d）移行型。肺胞壁にそつて水腫液の附着が認 められ，或いは散在性に肺胞然が水腫液にて満さ れているもの，一方肺間質内肺水腫の程度につい ては肺血管壁，気管支壁及びその周囲組織並びに 小集間組織につき観察し，組織間隐中明ら加に認

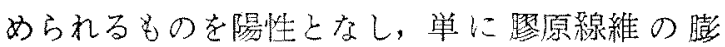
化，或は間隐を形成せるものを移行型となした。

\section{成 績}

I ）肺水腫発生頻度並びに肺胞内水腫と間質 内浮腫との関係

肺胞内水腫は 248例中 106 例 $(42.7 \%)$, 移行型 は35例 $(14.1 \%)$,水腫を認めないものは残りの 107例 (43.2\%)であつた。一方間質内浮腫は 248 例中64例 $(25.8 \%)$, 移行型は50例 $(20.2 \%)$, 浮腫 を認めないものは残りの134例（54.0\%）であつ た（表Ｉ）。肺胞内水腫の頻度は間質内浮腫のそ れより大きく，加雨者の移行型を含めても肺胞 内水腫の発生率が高い. 肺胞内, 間質内共に水腫 発生をみたもの58例，共に水腫発生をみないもの 85例でこの一致をみる事は当然であるが，他方一 致しない它の23例，間質内浮腫があつて肺胞内水

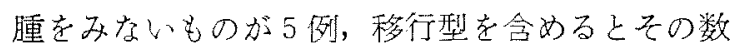
は倍加し，肺胞内水腫区び間質内浮腫の間に明ら かなる相関々係屿みられない。

II）肺水腫の疾患别発生頻度

7 禾統の疾患別にみた肺水腫の笔生頻度は中枢

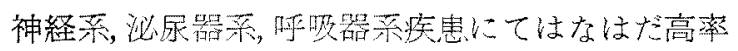
である。泌录器系疾患では肺胞内肺水腫の発生例 の殆ど全例に間質内浮腫を伴なつているに区し， 中枢神経系, 呼吸器柔疾患では肺胞正び間質内肺
Table V. Incidence of Pulmonary Edema in Pulmonary Tuberculosis, Tuberculous Meningitis and Combined Cases

\begin{tabular}{|c|c|c|}
\hline & No. of Cases & Intraalveolar Edema \\
\hline Pulm. The. & 23 & $39.1 \%$ \\
\hline Meningitis tbe. & & $4 \quad 100 \%$ \\
\hline Combined & 15 & $10 \quad 66.7 \%$ \\
\hline
\end{tabular}

Table VI. Number of Central Nervous Disorders combined with Cardiovascular Disorders in Edema and Non-edema Group

\begin{tabular}{|l|c|c|}
\hline & No. of Cases & No.ot Central Nerrous D. \\
\hline Edema Group & 9 & 3 \\
\hline Nom-edena Group & 12 & 0 \\
\hline
\end{tabular}

Table VII. Incidence of Pulmonary Edema in Brain Tumor and Other

\begin{tabular}{|l|c|cc|}
\hline & No.of Cases & Iotraalvelar Edema \\
\hline Brain Tumor & 11 & 8 & $72.7 \%$ \\
\hline 0thers & 76 & 18 & $23.7 \%$ \\
\hline
\end{tabular}

水腫の合併率がや>劣り, 循環器柔疾患では更に 低率であつた（表II）。

III）肺胞内肺水腫発生群之非発生群に於汁る 肺の病理組織像

表に示す如く肺水腫発生群 106例中，白血球楁 出74例 $(69.8 \%)$ ， うつ血98例 $(92.5 \%)$, 出血 43 例 $(40.6 \%)$ で非発生群 107 例中, 白血球渗出 12例 $(11.2 \%)$ ，うつ血44例 $(41.1 \%)$, 出血 9 例 ( $8.3 \%)$ であつた（表).

IV) 疾患別にみた肺水腫発生群と非発生群に 於ける肺の病理組織像

肺水腫発生群にては何れの系統の疾患において もその大多数に肺毛細管のうつ血を認めるが(90 \%以上), 非発生群にては約半数に認めるに過ぎな い.白血球渗出，出血の病理像についてみると疾 患别に相当の差異があり，中枢神経疾患，偱環器 疾患の肺水腫発生群中 $20 \sim 40 \%$, 㭔吸器疾息, 血液疾患ではその過半数に認めた。非発生群ては うつ血像以外，はなはだ所見に元しかつた(表V).

V) 眠水腫と中枢神経障害との関連 
呼吸器系疾患においては前項からもわかるよう に, 感染症或は感染の併発が多いためにその肺水 腫は炎症性機転に関係すると考えられるがここれ らの中で殊に肺結核を採りあげてみると表 Vの如 くである. 即ち肺結核単独, 結核性脳膜炎単独, 及びその両者の合併の 3 群に分けて肺水腫の発生 狀態をみるとそれぞれ23例，4例，15例で肺結核 単独の23例中肺水腫は 9 例 $(39.1 \%)$ であるに対 し, 後 2 者合計19例中肺水腫14例 $(73.7 \%)$ で明 らかな差を認めた。

循環器疾患においては21例中 9 例に肺水腫をみ たが，中枢神経障害を合併したものが 3 例であつ た・肺水腫を認めなかつた症例中には中枢神経障 害例はなかつた（表V）.

中枢神経系の腫瘍は11例でその中 8 例に肺水腫 を認めるが，その他の部位の腫癔では76例中18例 で耐者の間にはなはだしい発生頻度の差が認めら れる(表VII).

\section{考案}

肺水腫が剖検肺にて相当高率に認められたが， 肺胞内水腫と間質内浮腫の相関々係をみる合併 例分単独例に比し著しく高率を示している. 即ち 合併例は58例, 単独例は肺胞内水腫のみ23例, 間 質内浮腫のみ 5 例であつた。即ち両者の間には相 関々係は認め難かつた. 又肺胞内水腫発生例 106 例中，間質内浮腫を認めたものは58例（54.7\%） で, 間質内浮腫発生例 64 例中, 肺胞内水腫は58例 (90.6\%) で両者の間に著しい差を認めた。

この事は，（1）肺胞内水腫と間質内浮腫とが 同時に発生したとしても, その程度に差異がある か, 又は水腫液の処置機転の差異によるものか, さもなくば，（2）両者が無関係に発生すること によると考えられる。

（1）両型の水腫が同時に発生する場合

こ>で水腫の発生部位についても考慮を要する と思う. 即ち肺胞内水腫は肺の最末梢部肺胞に各 所相次いで発生するであろう。その時同時に最末 梢部即亏肺胞間の間質にも浮腫の発生する事は, 吉田7) が電子顕微鏡学的に確かめているところで
ある.かように同時性, 同所性に肺胞内にも間質 内にも浮腫が発生する. 恐らくこの様な型の発生 が通例と思われる.この場合両型の間に程度の差 異をみることは因難な事であるが，水腫液が同一 の源をもつ以上，水腫液の量的差異があるとする ならば，それは液を包容する組織の側の条件によ るのであつて当面の問題ではない. 然ら岲問題は 排泄処置の差異である. 肺の最末梢部の間質の浮. 腫液は細胞間液となつてリンパ管系を経て排泄さ れる.肺胞内水腫液は岡田8) の言う如く直接毛細 管に吸収されるか，間質に吸収されてリンパ管系 によるか, 或は気道を経て外界へ運び去られるか。 の三つの経路をとつて処置されるが, 岡田8) は毛 細管よりの吸収を重視している・リンパ管系によ る排泄は，肺におけるかつる危機の際には極度に 利用されるとしても過大評価することは出来な い. 故に肺胞内水腫と間質内浮腫が共に小循環系 の毛細管より発生したとしても, 両者の水腫液の

Fig. 1. Dilated Periarterial Lymphatic Duct in the Experimental Producing Pulmonary Edema in Rabbit



排泄処理の能率には上述の椂に差異があるがら， 排泄の遲速を来たして肺胞内及び間質内の浮腫が. 全く一致して存在しない事が起り得よう.

2）両型が無関係に発生する場合

我々は吉田7）が電子顕徽鏡学的に認めた肺末梢: に於ける間質の浮腫から，光学的に認められる間 質に於ける浮腫に発展するものとして前項におい て論じた。この事は Tobin9)による肺リンパ系 に示された如く, 肺の末梢間質の浮腫液が肺動脈 
周囲のリンパ管で運び去られる事を，我々の家鬼 に於けるアドレナリン肺水腫実験の水腫肺にて間 質内浮腫と共に肺動服周畔リンパ管の著しい拡張 として認めた（図 I ).

しかし異論唯あるするならば，それは光学顕 微鏡的の間質浮腫は只に肺の最末梢部の間質浮腫 液に由来するのみでなく，肺の栄荃血管柔たる気

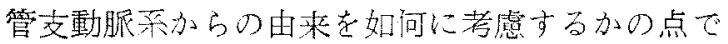
あ万う。中村100の言う如く，小偱環系之大循環系 の一分枝たる気管支血管の間に短結があり機能的 にも波接な関係在有しているのであるから，かっ る識別が容易てないことはいうまでもない。しか し我々の成績の中からこの考えを支持するものを 抽出するならば，大循環秀の毛細管障害が認めら れる泌沓器系疾患においては，殆に゙全例に肺胞内 水腫と間質内浮腫との合话を認めたことである。 大循環柔に於ける浮腫を主徵候の一つ上する循環 器柔疾患において, 前者上同様の関連が期待され るのであるが，我々の成績（循環器采疾患の症例 が過少てあるが)では，期待に区し間質浮腫の発 生が非常に低率であつた。この事は循環障寒のあ る時の肺水腫が，一つに㣪方障害に基因すると考 えられる所見である。とも加く間質浮腫の笔生が 低率なこと，殊に肺胞内水腫なくして間質のみに 認められるものが 5 例に過きないことは，前述の 排淮処理の幄速の他に肺に於计る大循環秃流血量 が，全流拞量の1〜2\%に過ぎ店い事実上り気管 支動服系より間質浮腫を発生する程度が軽微と考 えられる。この專は勿論前述した循環器疾患にお いて，予期に反して間質内浮腫が少なかつた事に 関連する。即ち徭力障害に上る肺循璦の障害が压 倒的で気管支動脈录加らの浮腫と比較にならない ということである.従つて我々の成績中移行型が 問題となるが，我乃の用いた力法を以ては軽微な 浮腫をとりあげて論ずるのは不適当と考えるので 将来の研登に期待したい。

病理組織学的にみた肺水腫像；

剖検肺の病理組織については前述の如く, 肺水 腫の有無以外，肺うつ血，肺胞内の白血球渗出及
び出血の三つの所見を主体として観察したのであ るが,肺水腫発生群にては，うつ血は92.5\%，白血 球滲出は69.8\%, 出血は40.6\%であり非発生群に てはうつ血 $41.1 \%$, 白血球滲出 $11.2 \%$, 出血 8.3 \%であつた，即ちうつ血が肺水腫の有無に拘らず 高率であり，肺水腫が発生するに抢よびいよいよ 高率になる事から肺水腫の発生に粲密な関係のあ る事が容易に考えられる.Jordan は肺水腫の程 度の分類にて，肺毛細管のうつ血を必須要項の中 に入れている。一方白血球渗出は出血と同様非発 生群の場合には低率に認められるに過ぎないが， 白血球渗出は肺水腫発生群では出血に此し遥かに 高事である事から，白血球渗出方肺水腫発生と関 倸が染いと考えられるが，原因と导結果とも判別 は出来ない。しかし少なく共原因的存在であるも のが少なくないといえる．出血に関しては原因と 考える根执が炎しい。

こ〉で肺水腫の組織像よりみて, 肺水腫をうつ 血性と炎症性に分けて考えてみる。 うつ血性肺水 腫は毛細血管のうつ血が極めて著明で，肺胞内若 しくは間質内に肺水腫を認め，その他の所見に乏 しいものである。一方炎症性肺水腫はうつ血性肺 水腫の組織像に加うるに肺胞内に白血球渗出, 出 血が認められ，肺胞壁を構成せる上皮及び内被細 胞に膨化，排列の異常或は水腫液内に線維の渗出 があり，い和ゆる炎症象の色彩の濃いものである。

汃くの如く病理像上りみると循環器系, 中枢神 経系及な゙泌尿器系疾患にみられる肺水腫はうつ血 性肺水腫に属し, 呼吸器系のそ机は炎症性肺水腫 に属する。

肺水腫と中枢神経障䇺との関連性;

各采統別に脑水腫の発生頻度をみると表 II 如 く，中枢种経系にて電めて高率 $(68.3 \%)$ であ り，锭来既に発表された諸家の循環器疾息，或は心 不全を合併せる疾患に高率であるという報告とは 相違しており，我々の得た成繢ては循環器疾患(他 疾患に比し例数が少ないが) では，42.9\% と予想 外に低率であつた。

慢性炎症性疾患である肺結核ではむしろ，うつ 
血性肺水腫像を示している事は興味ある事で，そ の発生例数の $50 \%$ が脳膜资合併している事よ り，肺結核では脳膜等の障害という神綎因子が肺 水腫発生要因に大きな役割をしめているように思 われる。

更に中枢神経系に於ける睡瘍では，肺水腫の発 生頻度は72.7\%て極的て高率で，他の身体各部の 腫演例ではそれに比し $23.7 \%$ と著しい差が認めら れる。文中枢神経系の障害部位と肺水腫発生の相 関々係をみるに，脳下垂体及び綏橋障害例の全例 に高度の肺水腫を認めた以外，障害部位と無生頻 度或は病理組織の間に特別な傾向は認めなかつ た。

以上の各項より中枢神経障害, 即方神経因子が 肺水腫発生に重要な役割をしめている事が考察さ れた。

\section{要 約}

本袁告に呈示した 248 例の剖模肺の病理組織学 的开究により
（1）肺胞内水腫と間質内浮腫に分けて钼祭し た。

（2）この両者を分離した所以を检討した。

（3）組織学的にうつ血性と炎症性とに分けて 観察したとこ引，殊に後者例中において中枢蚛経 障害分登生に関与すると洘元られるいくつかの成 續が示された。

\section{文献}

1) Altschule M.D.: Grune \& Stratton New York 1954. - 2) Cameron, G.R.: Brit. Med. J. $1: 965,1948 .-3)$ Luisada A.A. \& L. Cardi: Circulation $13: 113$, 1956. - 4) Paine R.: J. A.M.A. $149: 643 ， 1952$ ， -5) 商薄十六他：时 吸之循環， $2: 176,1954,-6)$ 勝木司黑之助他: 呼吸之循環，3:658，1955。-7) 吉田稳他：日 本循環器学誌, $21: 181,1957,-8)$ 间田庱夫 : 第

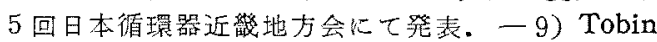
C.E.: Anatomical Record, 120 : 625, 1954. 10）中村隆: 気管支血管采の研究, 医学書院, 東 京, 1957. - 11) Jordan: Arch. Surg. 63:119, 1951. 